\title{
What Factors Influence European Corporate Bond Spread?
}

\author{
Maria Cristina Arcuri ${ }^{1}$, Gino Gandolfi ${ }^{2}$, Manou Monteux ${ }^{3} \&$ Giovanni Verga $^{2}$ \\ ${ }^{1}$ Department of Economics and Management, University of Florence, Florence, Italy \\ ${ }^{2}$ Department of Economics and Management, University of Parma, Parma, Italy \\ ${ }^{3}$ Genesis ML Solutions Ltd, London, UK \\ Correspondence: Maria Cristina Arcuri, Department of Economics and Management, University of Florence, via \\ delle Pandette 9, 50127, Florence, Italy. E-mail: mariacristina.arcuri@unifi.it
}

Received: January 31, 2020

Accepted: February 22, 2020

Online Published: March 12, 2020

doi:10.5539/ijbm.v15n4p87

URL: https://doi.org/10.5539/ijbm.v15n4p87

\begin{abstract}
This paper examines the main determinants of corporate euro-bond spread. We analyse a large sample of corporate euro-country bonds over the period May 2005 -January 2012, considering three sub-periods: May 2005- July 2007 (pre-crisis period), August 2007-April 2010 (worldwide financial crisis) and May 2010-January 2012 (European sovereign debt crisis).

We show that both liquidity risk and risk related to the country of the issuing firms affect corporate bond spread. We also find that the market yield of corporate bonds issued in the main European countries is, other things being equal, strongly influenced by the risk of the corresponding sovereign bonds and Credit Default Swap (CDS). Finally, we compare the yields of bonds issued by banks with those of bonds issued by firms from other sectors and find that the spread, other things being equal, is significantly higher for banks. These findings may have operating implications for market activity, regulators and policy makers.
\end{abstract}

Keywords: bid-ask spread, bond, CDS, country risk, credit spread, liquidity risk

\section{Introduction}

The level of liquidity is critical to effective financial market functioning. Liquidity can be considered a multidimensional concept (Sommer \& Pasquali, 2016): it refers to the ability to execute large transactions with limited price impact, and it tends to be associated with immediacy in execution and low transaction costs. Liquidity showed its great importance during the financial crisis of 2007-2008 when the financial system was unable to absorb unpredictable shocks and maintain market-wide liquidity.

Our paper analyses the effects of liquidity and risk premium on corporate bond spread during the period from May 2005 to January 2012, dividing it into three sub-periods: May 2005- July 2007, the pre-crisis period, August 2007-April 2010, the worldwide financial crisis, and May 2010-January 2012, the European sovereign debt crisis.

The issue of corporate bond market liquidity attracts great attention among financial institutions, regulators and policy makers (Bao et al., 2018; Gabor \& Ban, 2015; Trebbi \& Xiao, 2019). It is a complicated and controversial debate, so consistently with previous literature, we consider default risk measures, including rating and corporate bond CDS, and both direct and indirect measures of liquidity. Liquidity is, in fact, an important determinant of corporate bond yield spread: corporate bond prices include a premium for illiquidity, and internal liquidity risk should be incorporated into bond yield spread modeling (Chen et al. 2011; Helwege et al., 2014; Houweling et al 2005). We also consider country risk, in other words, the risk that a national government may default on its bonds or other financial commitments.

The study aims to answer the following research questions: (1) Do liquidity and country risk affect the European corporate bond spread? (2) Do sovereign bonds and CDS influence the market yield of European corporate bonds? (3) Are there differences between the spread of bonds issued by banks and the spread of other corporate bonds?

We analyze the determinants of European corporate bond spread considering various measures of liquidity and default risk and investigating the extent to which bond spread is influenced by the country where securities are issued. We find that liquidity and country risk affect the corporate bond spread, and sovereign bonds and CDS 
affect the market yield of corporate bonds. In order to examine the determinants of spread when the economic and financial situation changes, we carry out the analysis in the overall period from May 2005 to January 2012 and in three sub-periods corresponding to the worldwide financial crisis, the pre-crisis period and the European sovereign debt crisis.

Finally, we compare bonds issued by the banking and non-banking sectors, and find that, other things being equal, the spread of bonds issued by banks is significantly higher than that of other corporate bonds.

Previous literature has shown that the role of liquidity in bond spreads to be a debatable topic: corporate bond spreads contribution from an illiquidity risk factor has been shown to be paramount during the 2008-2009 financial crisis (Dick-Nielsen et al. 2012), while it has been proposed that there is no evidence of a contribution of liquidity to the Euro-zone sovereign spread moves (Oliveira et al. 2012) during the same period. The role of liquidity during the European sovereign debt crisis is also controversial: liquidity has been found as irrelevant factor explaining European financial institutions CDS spreads moves (Annaert et al. 2013), while other authors have shown liquidity to be a primary determinant of sovereign spreads (De Santis 2014). Further, interdependence of the default risk of several Eurozone countries and their domestic banks has been explored (Alter and Schüler 2012) as well as the link between Euro sovereign credit spreads and credit spreads of the non-financial corporate sector in the Eurozone (Bedendo and Colla 2015).

The results of our findings complement the existing literature by analysing in conjunction liquidity, bond spread, CDS spreads, country effects and the difference between financial and non-financial institutions, across three different market regimes: pre-crisis, global financial crisis and European sovereign debt crisis. Our analysis, by leveraging a broad and granular panel dataset representing the whole Euro-denominated bond market, would like to add some clarity regarding the role of liquidity, the links between European sovereigns spreads and banks credit spreads, concurrently considering also the split between financial versus non-financial issuers.

The remainder of this paper proceeds as follows. Section 2 presents a literature review on liquidity and risk in bond markets. Section 3 describes our large sample of corporate bonds and the methodology we applied. Section 4 shows the results we obtained and Sections 5 and 6 provide a discussion and conclusions.

\section{Literature Review}

Liquidity impacts financial market prices (Collin-Dufresne et al. 2001; Chung and Hrazdil, 2010; Jacoby et al. 2000; Kondor \& Vayanos, 2019; Üslü, 2019). In general, the lack of liquidity is a negative component of asset price and therefore affects asset returns (Amihud \& Mendelson 1989; Brennan et al. 1998; Chen et al., 2018, 2007; Grossman and Miller, 1988; Huang and Wang, 2009; Lin et al. 2011).

In the literature on stocks, many studies (e.g. Benston \& Hagerman 1974; Datar et al. 1998; Ma et al., 2018; Stoll 1978) identify trading activity, volatility and prices as sources of liquidity. Holmstrom and Tirole (2001) and Gu et al. (2019) incorporate liquidity risk into the traditional asset pricing theory. Acharya and Pedersen (2005) decompose liquidity risk into three sources of risk: the covariance of individual stock liquidity with market-wide liquidity, the covariance of individual stock return with market-wide liquidity and the covariance of individual stock liquidity with market returns. Amihud (2002) finds that liquidity predicts expected returns in time-series, while Pastor and Stambaugh (2003) observe a cross section relationship between expected stock returns and liquidity risk. Amihud and Mendelson (1989) analyze the link between the bid-ask spread and the expected return and show that the bid-ask spread is positively related to the expected return. According to the Capital Asset Pricing Model (CAPM), asset returns are determined by their systematic risk (i.e., $\beta$ ). The market model considers the return on asset $(j)$ in a period $(t)$ as a function of the market return $\left(R_{m t}\right)$, that is: $R_{j t}=\alpha_{j}+\beta_{j} R_{m t}+$ $\varepsilon_{\mathrm{jt}}$. Chordia and Swaminathan (2000) and Brennan et al. (1998) find a negative relation between trading volume and expected returns. Other studies (Campbell and Ammer 1993; Fleming et al. 1998; Ho and Stoll 1983; Lin et al., 2018; O'Hara and Oldfield 1986) find that liquidity in stock and bond markets covaries. Downing et al. (2005) find that systematic liquidity risk factors in Treasury bond and equity markets are also priced in corporate bonds. Some papers (Daves \& Ehrhardt 1993; Fleming 2002; Kamara 1994; Krishnamurthy 2002; Longstaff 2004; Warga 1992) analyze the Treasury bond market measuring the impact of liquidity on expected returns. Bongaerts et al. (2017) find that liquidity and exposure to equity market liquidity risk affect expected bond returns. In general, bonds are less frequently traded than equities and transaction costs are higher, and consequently the effects of market liquidity are stronger in the bond market. Thus, we focus on this kind of financial market.

Sadka (2005) finds that liquidity is a systematic risk factor: investors usually demand a liquidity premium for holding illiquid securities in corporate bond markets. De Jong and Driessen (2012) estimate the excess corporate bond return in comparison with the market, including the exposure to changes in the liquidity factors. Chen et al. 
(2007) calculate the unobserved "true" bond return for a certain bond and the day that investors would bid given zero liquidity costs. They price corporate bonds by considering two factors: interest rate and equity market return. Anand et al. (2017) and Bao et al. (2011) using age, issuance, and trading activities as measures of illiquidity and liquidity proxies, find that lack of liquidity in corporate bond markets is economically significant. Mullineaux and Roten (2002) and Gebhardt et al. (2005) find that some bond characteristics, including size and frequency of issue, are significant, even outside the Fama-French model. Chordia et al. (2001) study the effect of the level and the volatility of trading activity and Chordia et al. (2005) suggest the existence of a link between money flows and transaction liquidity. Other contributions (Hasbrouck and Seppi 2001; Huberman and Halka 2001; Mancini et al., 2013) show that there is a significant co-movement of asset liquidity with market-wide liquidity.

Schultz (2001) investigates effects of liquidity using transaction based data. Febi et al. (2018) and Hong and Warga (2000) state that bid-ask spread is associated with proxies for risk and liquidity. The bid-ask spread is a very important indicator of illiquidity (Bessembinder et al., 2006; Edwards et al., 2007; Goldstein et al., 2007), but other aspects, for example, market depth, should also be considered. Chen et al. (2007) use the following liquidity measures: the bid-ask spread, the liquidity proxy of zero returns and a liquidity estimator based on a model variant of Lesmond et al. (1999). Nashikkar et al. (2008) introduce a measure of latent liquidity related to bond-specific characteristics (i.e., age, coupon, rating, maturity) and find that bonds with higher latent liquidity are more expensive relative to their CDS contracts, after controlling for other realized measures of liquidity. Blanco et al. (2005) investigate the co-integration relationship between corporate bond spreads and CDS spreads, documenting a strong non-default component in corporate bond yields.

Lin et al. (2011) study the potential effects of the liquidity and default information embedded in bond-specific characteristics. They analyse the pricing of liquidity risk in a cross section of corporate bonds and find a positive and significant relation between expected corporate bond returns and liquidity risk. Chen et al. (2007) also find that more illiquid bonds earn higher yield spreads. Houweling et al. (2005) obtain similar results for the euro corporate bonds. They proxy the bond liquidity by using a set of aspects, including issued amount, coupon, age, missing prices, yield volatility, number of contributors and yield dispersion. Dìaz and Navarro (2002) also focus on the euro bond market. They find a downward sloping term structure of yield spreads for investment-grade bonds and state that this outcome is mainly due to the effect of liquidity on yield spreads. Ericsson and Renault (2006) find a positive correlation between the illiquidity and default components of yield spread. Several studies decompose the corporate bond spreads into default and non-default components. Longstaff et al. (2005) find that the non-default component is closely related to bond specific illiquidity measures and relate it to liquidity variables, such as coupon, bid-ask spread, amount outstanding and so on. Illiquidity in corporate bonds has important economic implications on bond yield spreads and varies substantially over time, along with changing market conditions. Acharya et al. (2013) show that the pricing of liquidity risk in the bond market is conditional on the state of the economy, with liquidity risk becoming more important in times of financial and economic distress. Huang and Wang (2009) find that the impact of illiquidity on the market is transitory.

Schwarz (2019) uses a model-free measure of market liquidity to identify the contribution of credit versus liquidity to spreads in the global financial crisis and the subsequent European debt crisis, when Euro-area sovereign bond and interbank interest rate spreads spiked. He finds that during the financial crisis, liquidity accounts for $36 \%$ of trough-to-peak widening whereas in the debt crisis default risk becomes relatively more important to sovereign spreads. Friewald et al. (2012) state that the economic impact of the liquidity measures is greater in periods of crisis, and for speculative grade bonds. At the onset of the subprime crisis, the liquidity component rose for all rating classes except AAA. Dick-Nielsen et al. (2012) find this is due to the decrease of bond liquidity and to the increased sensitivity of bond spreads to illiquidity. They also investigate whether the time-series variation of liquidity of corporate bonds issued by financial firms is different from the variation for bonds issued by non-financial firms. They do not find any differences, except in extreme stress periods, where bonds of financial firms became very illiquid. An explanation for this could be the information asymmetry regarding financial firms.

\section{Data and Methodology}

\subsection{Data}

We analyze a sample of 1,762 corporate bonds issued in the main euro countries with the corresponding CDS and rating existing and residual maturity under 13 years (Note 1). Our sample is derived from the European Monetary Union (EMU) Broad Market Index (Note 2). Bonds which are subordinated or covered and securitization are excluded from the sample because of their nature as non-pure debt instruments. The bond quote source is the CBBT (Composite Bloomberg Bond Trader). All 5 year CDS associated with the specific 
bond were downloaded; if no CDS was associated with the issuer, the CDS of its parent issuer were searched. Where the parent company issuer had no CDS either, the CDS of the ultimate parent company was downloaded. If the ultimate parent had no active CDS quote either, then no CDS was considered in our analysis. The CDS source is the CBIL (Composite Bloomberg Intraday London). Table 1 shows descriptive statistics of variables included in our analysis.

Table 1. Descriptive statistics

\begin{tabular}{lccccc}
\hline \multicolumn{1}{c}{ Variables } & Mean & Median & Max & Min & Std. Dev. \\
\hline$\Delta$ Yield to maturity of bonds ${ }^{\prime}$ & -0.001 & 0.000 & 15.805 & -15.815 & 0.122 \\
$\Delta$ Risk-free yield (RFC) & -0.002 & -0.000 & 0.304 & -0.272 & 0.043 \\
SPREAD & 0.782 & 0.418 & 44.728 & -15.474 & 1.520 \\
Bid-Ask spread (BIDASK) & 0.21140 & 0.10000 & 58.90000 & -1.85500 & 0.48349 \\
Price Volatility (VOLATILITY) & 0.00309 & 0.00220 & 0.08648 & 0.00000 & 0.00356 \\
Coupon & 4.69 & 4.625 & 10.150 & 0.00 & 1.182 \\
Maturity & 6.16 & 4.62 & 30.02 & 1.00 & 5.24 \\
LOG(Issued Amount) & 21.34 & 20.77 & 26.94 & 18.83 & 1.28 \\
Flat day on active days (IDLEDAYS) & 0.087 & 0.056 & 0.299 & 0.000 & 0.064 \\
Rating & 4.571 & 4.000 & 10.000 & 1.000 & 2.941 \\
CDS spread (BONDCDS) & 1.503 & 0.801 & 169.000 & 0.012 & 3.080 \\
Slope of the free-interest rate curve (SLOPE) & 0.586 & 0.425 & 2.796 & -0.679 & 0.669 \\
\hline
\end{tabular}

Note. The table reports summary statistics of variables used in our analysis. R is the bond yield. RFC is the corresponding free interest rate. A detailed definition of variables is provided in Section 5 .

\subsection{Methodology}

Our analysis is based on a panel data technique. Equation (1) summarizes our model.

$$
\mathrm{Y}_{\mathrm{i}, \mathrm{t}}=\beta_{0}+\beta_{1} \mathrm{x}_{\mathrm{li}, \mathrm{t}}+\ldots+\beta_{\mathrm{k}} \mathrm{x}_{\mathrm{kit}}+\varepsilon_{\mathrm{it}}
$$

The dependent variable $\left(\mathrm{Y}_{\mathrm{i}, t}\right.$, where $i=1, \ldots, \mathrm{n}$ and $\left.t=1, \ldots, \mathrm{T}\right)$ is the spread (SPREAD) between the yield to maturity of bonds (R) and their corresponding risk-free yield (RF). The risk-free yields were determined on the basis of the Eurirs (Euro interest swaps) of the same maturity adjusted for the presence of coupons. In particular, the RF was approximated by solving the following equation with respect to $\mathrm{i}^{\mathrm{F}}$ for every day and bond:

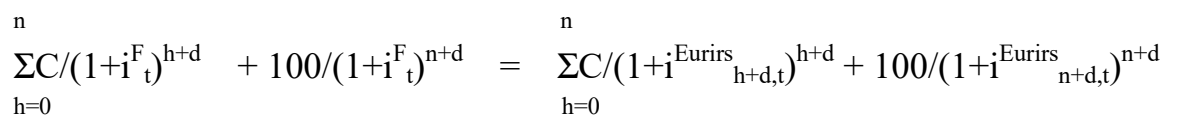

where: $\mathrm{c}$ is the coupon; $\mathrm{h}+\mathrm{d}$ is the time to maturity expressed in years $\mathrm{h}+$ days $/ 365.25 ; \mathrm{i}^{\text {Eurirs }} \mathrm{h+g}$ is the interpolation between Eurirs interest rates with maturities $h$ and $h+1$.

We use a set of independent variables ( $\mathrm{x}_{\mathrm{k}, \mathrm{it}}$ in Equation (1)), including direct measures of liquidity, which are the bid-ask spread (BIDASK) and the percentage of the zero-transaction days (IDLEDAYS), and indirect liquidity measures, e.g. the issued amount (AMOUNT). We also consider direct default risk measures, including the rating (RATING) and the CDS (BONDCDS) and indirect default risk measures, which are the slope of the free-interest rate curve (SLOPE) and the risk-free yield (RFC). Finally, we include in our analysis some determinants of both liquidity and default risk: maturity (MATURITY), the coupon (COUPON) and price volatility (VOLATILITY).

\section{Results}

Our first results are reported in Table 2. We considered the whole period from May 2005 to January 2012 and the three sub-periods: (1) May 2005-July 2007; (2) August 2007-April 2010 and (3) May 2010-January 2012. The period from August 2007 to April 2010 corresponds to the worldwide financial crisis, and the period from May 2005 to July 2007 immediately precedes it. The period from May 2010 to January 2012 coincides with Eurozone sovereign debt crisis. In order to estimate the impact of issuer country on bond spread, dummies for the main euro countries (i.e., Austria, Belgium, Finland, France, Greece, Ireland, Italy, Portugal and Spain) are introduced into the model. There is no dummy for Germany, which is used as a benchmark. 
Table 2. Panel estimation of the corporate yield spread (SPREAD)

\begin{tabular}{|c|c|c|c|c|}
\hline & Period & & & \\
\hline Independent variables & $2 / 05 / 2005-31 / 01 / 2012$ & $3 / 05 / 2010-31 / 01 / 2012$ & $1 / 08 / 2007-30 / 04 / 2010$ & $2 / 05 / 200531 / 07 / 2007$ \\
\hline Constant & -0.1062 & -0.2166 & -0.2531 & $-0.1131 * *$ \\
\hline "Austria" & 0.0104 & 0.0151 & 0.0094 & $0.0147 * *$ \\
\hline "Belgium" & 0.0120 & 0.0328 & -0.0067 & -0.0135 \\
\hline "Finland" & 0.0204 & 0.0233 & $0.0437 *$ & $-0.0276^{* * *}$ \\
\hline "France" & $0.0144 * * *$ & $0.0241 * * *$ & $0.0154^{*}$ & $-0.0133 * * *$ \\
\hline "Greece" & $0.1796^{* * *}$ & $0.5179 * * *$ & 0.0029 & -0.0038 \\
\hline "Ireland" & $0.0817 * * *$ & $0.1167 * * *$ & $0.0998 * * *$ & $0.0404 * * *$ \\
\hline "Italy" & $0.0497 * * *$ & $0.0804 * * *$ & $0.0316^{* * *}$ & $0.0141 * * *$ \\
\hline "Portugal" & $0.1500 * * *$ & $0.2566 * * *$ & $0.0742 * * *$ & $0.0424 * * *$ \\
\hline "Spain" & $0.0521 * * *$ & $0.0759 * * *$ & 0.0177 & -0.0037 \\
\hline BIDASK $_{\mathrm{t}-1}$ & $0.0054 * * *$ & $0.0092 * * *$ & $0.0039 * * *$ & $0.0849 * * *$ \\
\hline IDLEDAYS & $0.1849 * * *$ & 0.0352 & $0.5016^{* * *}$ & 0.0017 \\
\hline Log(AMOUNT) & $0.0116^{* * *}$ & 0.0092 & $0.0209^{* *}$ & $0.0068 * * *$ \\
\hline RATING & $0.0119 * * *$ & $0.0092 * * *$ & $0.0232 * * *$ & $0.0159 * * *$ \\
\hline BONDCDS $_{\mathrm{t}-1}$ & $0.0035 * * *$ & $0.0013^{* *}$ & $0.0073 * * *$ & -0.0003 \\
\hline MATURITY & $0.0029 * * *$ & -0.0005 & $0.0055^{* * *}$ & $0.0117 * * *$ \\
\hline COUPON & -0.0015 & 0.0005 & 0.0001 & $-0.0136^{* * *}$ \\
\hline VOLATILITY $_{\mathrm{t}-1}$ & $0.1455 * * *$ & $0.1682 * * *$ & $0.2077 * * *$ & $-0.1757 * * *$ \\
\hline SLOPE & $-0.0089 * * *$ & $-0.0036 * * *$ & $-0.0122 * * *$ & $-0.0030 * * *$ \\
\hline $\operatorname{SPREAD}_{\mathrm{t}-1}$ & $-0.0063 * * *$ & $-0.0055 * * *$ & $-0.0093 * * *$ & $-0.0161 * * *$ \\
\hline $\mathrm{RF}_{\mathrm{t}-1}$ & $-0.0051 * * *$ & $-0.0012 *$ & $-0.0080 * * *$ & $-0.0019 * * *$ \\
\hline$\Delta(\mathrm{RF})$ & $-0.3467 * * *$ & $-0.3640 * * *$ & $-0.3132 * * *$ & $-0.5192 * * *$ \\
\hline$\Delta\left(\mathrm{RF}_{\mathrm{t}-1}\right)$ & $0.0516^{* * *}$ & $-0.0828 * * *$ & $0.0953 * * *$ & $0.0807 * * *$ \\
\hline$\Delta\left(\mathrm{R}_{\mathrm{t}-1}\right)$ & $-0.2214 * * *$ & $-0.1136 * * *$ & $-0.2398 * * *$ & $-0.2212 * * *$ \\
\hline$\Delta(\mathrm{BIDASK})$ & $0.0275 * * *$ & $-0.0475 * * *$ & $0.0202 * * *$ & $0.4078 * * *$ \\
\hline$\Delta(\mathrm{BONDCDS})$ & $0.0486^{* * *}$ & $0.0908 * * *$ & $0.0396^{* * *}$ & $-0.1745 * * *$ \\
\hline$\Delta($ VOLATILITY) & $0.9600 * * *$ & $0.6650 * * *$ & $1.4098 * * *$ & $-0.3099 * * *$ \\
\hline Adjusted R-squared & 0.0777 & 0.0461 & 0.0946 & 0.6295 \\
\hline Durbin-Watson stat & 2.0073 & 1.9909 & 2.0183 & 2.4231 \\
\hline Included observations after ADJ & 1,762 & 473 & 718 & 587 \\
\hline Cross-sections included & 747 & 572 & 615 & 339 \\
\hline Total pool (unbalanced) observations: & 636,846 & 232,203 & 270,442 & 141,383 \\
\hline
\end{tabular}

Note. The table reports the panel estimation of the corporate yield spread during the whole period (May 2005-January 2012) and the three sub-periods considered in our analysis (August 2007-April 2010, May 2010-January 2012 and May 2005-July 2007). Significance is expressed with one, two or three asterisks, i.e. the rejection of the hypothesis of values equivalent to 0 with a probability level equal to $10 \%$, $5 \%$ or $1 \%$. Country dummies refer to the corresponding bond issuer country. Dependent variable: SPREAD $\equiv \mathrm{R}-\mathrm{RF}$. Daily data.

Table 2 shows that the lagged dependent variable SPREAD $_{t-1}$ has a negative coefficient, confirming that $\mathrm{SPREAD}=\mathrm{R}-\mathrm{RF}$ always tends to its equilibrium value. As in previous literature, numerous explanatory variables (i.e. BIDASK, RATING, BONDCDS, VOLATILITY, SLOPE and RF) are always significant. Other explanatory variables (i.e. IDLEDAYS, Log (AMOUNT), MATURITY and COUPON) are not always significant, especially during the period May 2010 - January 2012.

Another important result is that the "country effect" appears very strong only during the period of sovereign debt crisis. In particular, the dummy variables coefficients of the PIIGS countries (Portugal, Ireland, Italy, Greece and Spain) are positive, significant and high. Moreover, their values are closely related to the corresponding Treasury bond CDS.

Since all dummy country-variables are closely related to their sovereign CDS values, we replicated the second equation of Table 2 (over the period May 2010-January 2012) replacing every dummy country-variable with the corresponding series of sovereign CDS (i.e. their spread with the Germany CDS). These variables (henceforth: COUNTRYCDS) were first introduced into our equation with different coefficients for each country. However, since the estimated coefficients appeared fairly homogeneous between all countries, we re-estimated our equation under the hypothesis that the coefficients of all sovereign CDS were the same. Results are reported in 
Table 3 for the sovereign crisis period. The adjusted R-squared improved compared with its corresponding value reported in Table 2, while all other coefficients remained almost the same.

Table 3. Panel estimation of the sovereign CDS impact on the corporate yield spread

\begin{tabular}{|c|c|c|c|c|c|}
\hline \multirow[b]{2}{*}{$\begin{array}{l}\text { Independent } \\
\text { variables }\end{array}$} & \multicolumn{4}{|c|}{ all corporate bonds } & \multirow[b]{2}{*}{ non banking sector } \\
\hline & all maturities & $\begin{array}{l}\text { maturity } \\
>3 \text { years }\end{array}$ & all maturities & all maturities banking sector & \\
\hline Constant & $-0.3516^{* *}$ & -0.1837 & -0.1096 & $-0.3002 * *$ & -0.1965 \\
\hline "Austria" & - & - & 0.0262 & - & - \\
\hline "Belgium" & - & - & 0.0417 & - & - \\
\hline "Finland" & - & - & 0.0278 & - & - \\
\hline "France" & - & - & $0.0265^{* * *}$ & - & - \\
\hline "Greece" & - & - & $0.6334 * * *$ & - & - \\
\hline "Ireland" & - & - & $0.1130^{* * *}$ & - & - \\
\hline "Italy" & - & - & $0.0873^{* * *}$ & - & - \\
\hline "Portugal" & - & - & $0.2337 * * *$ & - & - \\
\hline "Spain" & - & - & $0.0894 * * *$ & - & - \\
\hline COUNTRYCDS $_{\mathrm{t}-1}$ & $0.3979 * * *$ & $0.4685^{* * *}$ & - & $0.5035 * * *$ & $0.4823 * * *$ \\
\hline$\Delta($ COUNTRYCDS $)$ & $11.4594 * * *$ & $9.2400 * * *$ & - & $11.3026 * * *$ & $8.1500 * * *$ \\
\hline$\Delta\left(\right.$ COUNTRYCDS $\left._{\mathrm{t}-1}\right)$ & $8.8760^{* * *}$ & $8.5281 * * *$ & - & $8.8210 * * *$ & $7.4812 * * *$ \\
\hline dummy banks & - & - & $0.0629 *$ & $0.0976^{* * *}$ & - \\
\hline "Austria" & - & - & $-0.0648^{*}$ & $-0.0783 * *$ & - \\
\hline "Belgium" & - & - & $-0.0439 * *$ & -0.0728 & - \\
\hline "France" & - & - & $0.0376^{* *}$ & $0.0584 * *$ & - \\
\hline "Ireland" & - & - & $0.5140 * * *$ & $0.5550 * * *$ & - \\
\hline "Italy" & - & - & 0.0017 & 0.0027 & - \\
\hline "Portugal" & - & - & $0.2508^{* * *}$ & $0.3110^{* * *}$ & - \\
\hline "Spain" & - & - & $0.0491^{*}$ & $0.0597 * *$ & - \\
\hline BIDASK $_{\mathrm{t}-1}$ & $0.0094^{* * *}$ & $0.0053^{* * *}$ & $0.0076^{* * *}$ & -0.0014 & $0.0114 * * *$ \\
\hline IDLEDAYS & 0.0918 & 0.0914 & $0.1449^{*}$ & $0.4483 * *$ & $0.4163 * * *$ \\
\hline $\log ($ AMOUNT $)$ & $0.0121^{*}$ & 0.0045 & 0.0019 & $0.0869^{* * *}$ & -0.0014 \\
\hline RATING & $0.0151^{* * *}$ & $0.0197 * * *$ & $0.0168 * * *$ & $0.0499 * * *$ & $0.0273^{* * *}$ \\
\hline BONDCDS $_{\mathrm{t}-1}$ & $0.0019^{* * *}$ & $0.0028 * * *$ & -0.0002 & -0.0017 & $0.0059^{* * *}$ \\
\hline MATURITY & 0.0016 & 0.0005 & 0.0012 & -0.0071 & $0.0057 * * *$ \\
\hline COUPON & -0.0014 & 0.0038 & $0.0044 *$ & 0.0076 & 0.0029 \\
\hline VOLATILITY $_{\mathrm{t}-1}$ & $0.1655^{* * *}$ & $0.2260 * * *$ & $0.1859^{* * *}$ & $0.1228 * * *$ & $0.2117 * * *$ \\
\hline SLOPE & 0.0010 & -0.0006 & $-0.0062 * * *$ & -0.0007 & 0.0010 \\
\hline SPREAD $_{\mathrm{t}-1}$ & $-0.0067 * * *$ & $-0.0087 * * *$ & $-0.0072 * * *$ & $-0.0092 * * *$ & $-0.0104 * * *$ \\
\hline $\mathrm{RF}_{\mathrm{t}-1}$ & $-0.0023 * * *$ & $-0.0036 * * *$ & -0.0010 & 0.0031 & $-0.0033 * * *$ \\
\hline$\Delta(\mathrm{RF})$ & $-0.3096 * * *$ & $-0.3137 * * *$ & $-0.3625 * * *$ & $-0.3049 * * *$ & $-0.2877 * * *$ \\
\hline$\Delta\left(\mathrm{RF}_{\mathrm{t}-1}\right)$ & $-0.0191 * * *$ & $0.0168 * * *$ & $-0.0826 * * *$ & $-0.0726^{* * *}$ & $0.0168 * * *$ \\
\hline$\Delta\left(\mathrm{R}_{\mathrm{t}-1}\right)$ & $-0.1237 * * *$ & $-0.1648 * * *$ & $-0.1132 * * *$ & $-0.0263 * * *$ & $-0.1754 * * *$ \\
\hline$\Delta(\mathrm{BIDASK})$ & $-0.0481 * * *$ & $-0.1081 * * *$ & $-0.0483 * * *$ & $-0.0396 * * *$ & $-0.0537 * * *$ \\
\hline$\Delta(\mathrm{BONDCDS})$ & $0.0388 * * *$ & $0.1748 * * *$ & $0.0893 * * *$ & $1.1690 * * *$ & -0.0148 \\
\hline$\Delta$ (VOLATILITY & $0.6683^{* * *}$ & $0.7035^{* * *}$ & $0.6731 * * *$ & -0.1027 & $0.8352 * * *$ \\
\hline AdjustedR-squared & 0.0682 & 0.1201 & 0.0474 & 0.0754 & 0.0871 \\
\hline Durbin-Watsonstat & 2.0076 & 2.0131 & 1.9906 & 2.0533 & 1.9992 \\
\hline Included oservations & 718 & 457 & 457 & 457 & 457 \\
\hline Cross-sections included & 615 & 426 & 572 & 94 & 478 \\
\hline Total pool observations: & 270442 & 148918 & 225021 & 34554 & 190467 \\
\hline
\end{tabular}

Note. The table reports the panel estimation of the corporate yield spread during the sovereign crisis period (May 2010-January 2012). We replaced every dummy country with its corresponding series of sovereign CDS. The significance is expressed with one, two or three asterisks, i.e. the rejection of the hypothesis of values equivalent to 0 with a probability level equal to $10 \%, 5 \%$ or $1 \%$. The country names refer to the country dummies of the bond issuer. Dependent variable: SPREAD $\equiv \mathrm{R}-\mathrm{RF}$. Daily data. 
Our results confirm that the differences between the corporate yield spread of different countries are related to the risk of the corresponding sovereign bonds. Similar results are obtained if the spread between the various sovereign bonds and the Germany Bund yield are used instead of CDS. In order to check if this effect is stronger in case of long residual maturity, we estimated the same equation only for bonds of maturity longer than 3 years, (second column of Table 3), but no great difference emerged.

A further analysis compared the yields of bonds issued by banks and other corporate bonds. The hypothesis was that bond yields should be more sensitive to their corresponding country sovereign yields, since banks usually maintain a large amount of their country sovereign debt in their portfolio.

Results are shown in Columns (3) and (4) of Table 3. They were obtained by adding to the previous equations a dummy variable for every country considered. No dummy appears for Finland or Greece as no bank bonds were available. It emerged that the spread, other things being equal, is significantly higher for banks. The last column of Table 3 reports the estimation obtained for the non-banking sector. Since the number of its bonds is high, the coefficients are not very different from those in the first equation. Further analysis concerning the difference between the yield behaviour of industrial and banking bonds are provided in Appendix.

\section{Discussion}

The liquidity level in financial markets is a very important issue, and the efficient allocation of economic resources, the effectiveness of monetary policy and financial stability all depend on it. Taking into account the default risk and the country risk (i.e., the risk associated with the country where securities are issued), we examine the bond market. In particular, we try to answer the following research questions:

1) Do liquidity and country risk affect the European corporate bond spread?

2) Do sovereign bonds and CDS influence the market yield of European corporate bonds?

3) Are there differences between the spread of bonds issued by banks and the spread of other corporate bonds?

Like previous studies, we analyse the determinants of corporate bond spread, including when the economic and financial situation changes, considering periods of financial and economic distress, such as the worldwide 2007-08 financial crisis and the European sovereign debt crisis.

We find that both liquidity and risk can partly explain corporate yield movements, as well equilibria. Country effect is also a significant determinant of corporate bond spread. Moreover, we find that other things being equal, the corporate bond spread was higher in the countries where the public debt crisis was more serious, in the order: Greece, Portugal, Ireland, Spain and Italy. We show that sovereign bonds and CDS influence the market yield of European corporate bonds. Finally, we find that the spread of bonds issued by banks is higher than that of other corporate bonds. The exceptions are Belgium, and Italy, where banks are closely supervised by the Bank of Italy. The spread is higher in countries where the banking system faced more difficulties, particularly in Ireland.

Our study complement the existing literature by considering the role of liquidity in conjunction with bond spread and CDS spreads, while at the same time considering country effects and the difference between financial and non-financial institutions, across three different market regimes: pre-crisis, global financial crisis and European sovereign crisis. Our findings, based on a broad and granular dataset which can be considered a fair representation of the whole Euro-denominated bond market, complemented with a large CDS dataset, establishes more clarity about the role of liquidity in different market regimes and across different Eurozone countries and issuers types. As it is widely recognized, financial assets with low levels of liquidity tend to have high risk premia, and market participants tend to face high transaction costs and wide bid-ask spreads when trading in these securities. It follows that our results should be useful for supervisors, policy makers and regulators.

\section{Conclusions}

In this paper, the yield spread of corporate bonds issued in the euro-countries is analyzed using OLS panel data. The overall period considered was May 2005-January 2012, using daily data, but particular attention was paid to the worldwide financial crisis (August 2007-April 2010) and especially the Eurozone sovereign debt crisis (May 2010-January 2012). Our results show that liquidity factors need to be taken into account along with default risk indicators. The explanatory variables which proved most significant are in fact the following: bid-ask spread, price volatility, rating, bond CDS, risk-free term structure slope, risk-free rate. Another important variable usually explaining the bond spread is the percentage of non-traded days. Our findings show that during the sovereign debt crisis, the country where corporate bonds and their sovereign bonds CDS are issued has an enormous impact on bond yields. This impact seems to be stronger for bonds issued by the banking sector. However, there are significant differences between the countries considered: the country effect is very strong for 
Ireland, but insignificant for Belgium and Italy. These phenomena obviously create difficulties the euro-countries facing public debt problems. The bond yield spread is high in both sovereign and corporate sectors, so the cost of financing becomes higher in countries with restrictive public policies.

Many aspects of the euro-denominated bond market deserve to be further investigated, including the difference between euro-denominated bond yields issued in euro-countries and in the rest of the world, the interrelation between bonds and other markets during the crisis and the influence of ECB monetary policy on corporate and treasury bonds.

\section{References}

Acharya, V. V., Amihud, Y., \& Bharath, S. T. (2013). Liquidity risk of corporate bond returns: conditional approach. Journal of Financial Economics, 110(2), 358-386. https://doi.org/10.3386/w16394

Acharya, V. V., \& Pedersen, L. H. (2005). Asset pricing with liquidity risk. Journal of Financial Economics, 77, 375-410. https://doi.org/10.1016/j.jfineco.2004.06.007

Alter, A., \& Schüler, Y. S. (2012). Credit spread interdependencies of European states and banks during the financial crisis. Journal of Banking \& Finance, 36(12), 3444-3468. https://doi.org/10.1016/j.jbankfin.2012.08.002

Amihud, Y. (2002). Illiquidity and stock returns: cross section and time series effects. Journal of Financial Markets, 5(1), 31-56. https://doi.org/10.1016/S1386-4181(01)00024-6

Amihud, Y., Mendelson, H. (1989). The effects of beta, bid-ask spread, residual risk and size on stock returns. The Journal of Finance, 44(2), 479-486. https://doi.org/10.2307/2328600

Anand, A., Jotikasthira, C., \& Venkataraman, K. (2018). Do Buy-Side Institutions Supply Liquidity in Bond Markets? Evidence from Mutual Funds. 28th Annual Conference on Financial Economics and Accounting; SMU Cox School of Business Research Paper No. 18-5. Retrieved from https://ssrn.com/abstract=3003189 or http://dx.doi.org/10.2139/ssrn.3003189

Annaert, J., De Ceuster, M., Van Royb, P., \& Vespro, C. (2013). What determines Euro area bank CDS spreads? Journal of International Money and Finance, 32, 444-461. https://doi.org/10.1016/j.jimonfin.2012.05.029

Bao, J., O'Hara, M., \& Zhou, X. A. (2018). The Volcker Rule and corporate bond market making in times of stress. Journal of Financial Economics, 130(1), 95-113. https://doi.org/10.1016/j.jfineco.2018.06.001

Bao, J., Pan J., \& Wang J. (2011). The Illiquidity of Corporate Bonds. The Journal of Finance, 66(3), 911-946. https://doi.org/10.1111/j.1540-6261.2011.01655.x

Bedendo, M., \& Colla, P. (2015). Sovereign and corporate credit risk: Evidence from the Eurozone. Journal of Corporate Finance, 33, 34-52. https://doi.org/10.1016/j.jcorpfin.2015.04.006

Benston, G., \& Hagerman, R. (1974). Determinants of bid-asked spreads in the over-the counter market. Journal of Financial Economics, 1(4), 353-364. https://doi.org/10.1016/0304-405X(74)90014-2

Bessembinder, H., Maxwell, W., \& Venkataraman, K. (2006). Optimal Market Transparency: Evidence from the Initiation of Trade Reporting in Corporate Bonds. Journal of Financial Economics, 82, 251-288.

Blanco, R., Brennan, S., \& Marsh, I. (2005). An empirical analysis of the dynamic relation between investment grade bonds and credit default swaps. The Journal of Finance, 60(5), 2255-2281. https://doi.org/10.1111/j.1540-6261.2005.00798.x

Bongaerts, D., de Jong, F., \& Driessen, J. (2017). An Asset Pricing Approach to Liquidity Effects in Corporate Bond MarketsThe Review of Financial Studies, 30(4), 1229-1269. https://doi.org/10.1093/rfs/hhx005

Brennan, M. J., Chordia, T., \& Subrahmanyam, A. (1998). Alternative factor specifications, security characteristics, and the cross-section of expected stock returns. Journal of Financial Economics 49(3), 345-373. https://doi.org/10.1016/S0304-405X(98)00028-2

Campbell, J. Y., \& Ammer, J. (1993). What moves the stock and bond markets? A variance decomposition for long-term asset returns. The Journal of Finance, 48(1), 3-37. https://doi.org/10.2307/2328880

Chen, H., Cui, R., He, Z., \& Milbradt, K. (2018). Quantifying Liquidity and Default Risks of Corporate Bonds over the Business Cycle. The Review of Financial Studies, 31(3), 852-897. https://doi.org/10.1093/rfs/hhx107

Chen, T. K., Liao, H. H., \& Tsai, P. L. (2011). Internal liquidity risk in corporate bond yield spreads. Journal of Banking \& Finance, 35, 978-987. https://doi.org/10.1016/j.jbankfin.2010.09.013 
Chen, L., Lesmond, D., \& Wei, J. (2007). Corporate yield spreads and bond liquidity. The Journal of Finance, 62(1), 119-149. https://doi.org/10.1111/j.1540-6261.2007.01203.x

Chordia, T., Sarkar, A., \& Subrahmanyam, A. (2005). An empirical analysis of stock and bond market liquidity. The Review of Financial Studies, 18(1), 85-129. https://doi.org/10.1093/rfs/hhi010

Chordia, T., Roll, R., \& Subrahmanyam, A. (2001). Market liquidity and trading activity. The Journal of Finance, 56(2), 501-530. https://doi.org/10.1111/0022-1082.00335

Chordia, T., \& Swaminathan, B. (2000). Trading Volume and Cross-Autocorrelations in Stock Returns. The Journal of Finance, 55(2), 913-935. https://doi.org/10.1111/0022-1082.00231

Collin-Dufresne, P., \& Goldstein, R. S. (2001). Do credit spreads reflect stationary leverage ratios? The Journal of Finance, 56(5), 1929-1957. https://doi.org/10.1111/0022-1082.00395

Chung, D., \& Hrazdil, K. (2010). Liquidity and market efficiency: A large sample study. Journal of Banking \& Finance, 34(10), 2346-2357. https://doi.org/10.1016/j.jbankfin.2010.02.021

Datar, V., Naik, N., \& Radcliffe, R. (1998). Liquidity and stock returns: An alternative test. Journal of Financial Markets, 1(2), 203-219. https://doi.org/10.1016/S1386-4181(97)00004-9

Daves, P., \& Ehrhardt, M. (1993). Liquidity, reconstitution and the value of US Treasury strips. The Journal of Finance, 48(1), 315-329. https://doi.org/10.1111/j.1540-6261.1993.tb04712.x

De Jong, F., \& Driessen, J. (2012). Liquidity Risk Premia in Corporate Bond Markets. The Quarterly Journal of Finance, 2(2). https://doi.org/10.1142/S2010139212500061.

De Santis, R. A. (2014). The euro area sovereign debt crisis: Identifying flight-to-liquidity and the spillover mechanisms. Journal of Empirical Finance, 26, 150-170. https://doi.org/10.1016/j.jempfin.2013.12.003

Dìaz, A., \& Navarro, E. (2002). Yield spread and term to maturity: default vs. liquidity. European Financial Management, 8(4), 449-477. https://doi.org/10.1111/1468-036X.00199

Dick-Nielsen, J., Feldhutter, P., \& Lando, D. (2012). Corporate bond liquidity before and after the onset of the subprime crisis. Journal of Financial Economics, 103(3), 471-492. https://doi.org/10.1016/j.jfineco.2011.10.009

Downing, C., Underwood, S., \& Xing, Y. (2005). Is Liquidity Risk Priced in the Corporate Bond Market? Unpublished working paper, Rice University.

Edwards, A. K., Harris, L. E., \& Piwowar, M. S. (2007). Corporate bond market transaction costs and transparency. The Journal of Finance, 62(3), 1421-1451. https://doi.org/10.1111/j.1540-6261.2007.01240.x

Ericsson, J., \& Renault, O. (2006). Liquidity and credit risk. The Journal of Finance, 61(5), 2219-2250

Fama, E. F., \& French, K. R. (1993). Common risk factors in the returns on stocks and bonds. Journal of Financial Economics, 33(1), 3-56. https://doi.org/10.1016/0304-405X(93)90023-5

Febi, W., Schäfer, D., Stephan, A., \& Sun, C. (2018). The impact of liquidity risk on the yield spread of green bonds. Finance Research Letters, 27, 53-59. https://doi.org/10.1016/j.frl.2018.02.025

Fleming, J. (2002). Are larger Treasury issues more liquid? Evidence from bill re-openings. Journal of Money, Credit and Banking, 3(2), 707-735. https://doi.org/10.1353/mcb.2002.0013

Fleming, J., Kirby, C., \& Ostdiek, B. (1998). Information and volatility linkages in the stock, bond and money markets. Journal of Financial Economics, 49(1), 111-137. https://doi.org/10.1016/S0304-405X(98)00019-1

Friewald, N., Jankowitsch, R., \& Subrahmanyam, M. G. (2012). Illiquidity or credit deterioration: A study of liquidity in the U.S. corporate bond market during financial crises. Journal of Financial Economics, 105(1), 18-36. https://doi.org/10.1016/j.jfineco.2012.02.001

Gabor, D., \& Ban, C. (2015). Banking on Bonds: The New Links Between States and Markets. Journal of Common Market Studies, 54(3), 617-635. https://doi.org/10.1111/jcms.12309

Gebhardt, W., Hvidkjaer, S., \& Swaminathan, B. (2005). The cross section of expected corporate bond returns: Betas or characteristics? Journal of Financial Economics, 75(1), 85-114. https://doi.org/10.1016/j.jfineco.2004.04.002

Goldstein, M. A., Hotchkiss, E. S., \& Sirri, E. R. (2007). Transparency and Liquidity: A Controlled Experiment on Corporate Bonds. The Review of Financial Studies, 20(2), 235-273. https://doi.org/10.1093/rfs/hhl020

Grossman, S.J., \& Miller, M. (1988). Liquidity and Market Structure. The Journal of Finance, 43(3), 617-633. 
https://doi.org/10.1111/j.1540-6261.1988.tb04594.x

Gu, S., Kelly, B., \& Xiu, D. (2019). Empirical Asset Pricing via Machine Learning. NBER Working Paper No. 25398. https://doi.org/10.3386/w25398.

Hasbrouck, J., \& Seppi, D. (2001). Common factors in prices, order flows and liquidity. Journal of Financial Economics, 59(3), 383-411. https://doi.org/10.1016/S0304-405X(00)00091-X

Helwege, J., Huang, J., \& Wang, Y. (2014). Liquidity effects in corporate bond spreads. Journal of Banking \& Finance, 45, 105-116. https://doi.org/10.1016/j.jbankfin.2013.08.018

Ho, T., \& Stoll, H. (1983). The dynamics of dealer markets under competition. The Journal of Finance, 38(4), 1053-1074. https://doi.org/10.1111/j.1540-6261.1983.tb02282.x

Holmstrom, B., \& Tirole, J. (2001). LAPM: a liquidity based asset pricing model. The Journal of Finance, 56(5), 1837-1867. https://doi.org/10.1111/0022-1082.00391

Hong, G., \& Warga, A. (2000). An empirical study of bond market transactions. Financial Analysts Journal, 56(2), 32-46. https://doi.org/10.2469/faj.v56.n2.2342

Houweling, P., Mentink, A., \& Vorst, T. (2005). Comparing possible proxies of corporate bond liquidity. Journal of Banking and Finance, 29(6), 1331-1358. https://doi.org/10.1016/j.jbankfin.2004.04.007

Huang, J. C., \& Wang, J. (2009). Liquidity and Market Crashes. The Review of Financial Studies, 22(7), 2608-2643. https://doi.org/10.1093/rfs/hhn086

Huberman, G., \& Halka, D. (2001). Systematic liquidity. Journal of Financial Research, 24(2), 161-178. https://doi.org/10.1111/j.1475-6803.2001.tb00763.x

Jacoby, G., Fowler, D., \& Gottesman, A. (2000). The capital asset pricing model and the liquidity effect: a theoretical approach. Journal of Financial Markets, 3(1), 69-81. https://doi.org/10.1016/S1386-4181(99)00013-0

Kamara, A. (1994). Liquidity, taxes and short term Treasury yields. Journal of Financial and Quantitative Analysis, 29(3), 403-417. https://doi.org/10.2307/2331337

Kondor, P., \& Vayanos, D. (2019). Liquidity Risk and the Dynamics of Arbitrage Capital. The Journal of Finance, 74(3), 1139-1173. https://doi.org/10.1111/jofi.12757

Krishnamurthy, A. (2002). The bond/old-bond spread. Journal of Financial Economics, 66(2-3), 463-506. https://doi.org/10.1016/S0304-405X(02)00207-6

Lesmond, D., Ogden, J., \& Trzeinka, C. (1999). A new estimate of transaction costs. The Review of Financial Studies, 12(5), 1113-1141. https://doi.org/10.1093/rfs/12.5.1113

Lin, F., Yang, S., Marsh, T., \& Chen, Y. (2018) Stock and bond return relations and stock market uncertainty: Evidence from wavelet analysis. International Review of Economics \& Finance, 55, 285-294. https://doi.org/10.1016/j.iref.2017.07.013

Lin, H., Wang, J., \& Wu, C. (2011). Liquidity risk and expected corporate bond returns. Journal of Financial Economics, 99(3), 628-650. https://doi.org/10.1016/j.jfineco.2010.10.004

Longstaff, F. A., Mithal, S., \& Neis, E. (2005). Corporate yield spreads: default risk or liquidity? New evidence from the credit default swap market. The Journal of Finance, 60(5), 2213-2253. https://doi.org/10.1111/j.1540-6261.2005.00797.x

Longstaff, F. A. (2004). The flight to quality premium in US Treasury bond prices. Journal of Business, 77(3), 511-525. https://doi.org/10.1086/386528

Ma, R., Anderson, H. D., \& Marshall, B. R. (2018). Stock market liquidity and trading activity: Is China different? International Review of Financial Analysis, 56, 32-51. https://doi.org/10.1016/j.irfa.2017.12.010

Mancini, L., Ranaldo, A., \& Wrampelmeyer, J. (2013). Liquidity in the Foreign Exchange Market: Measurement, Commonality, and Risk Premiums. The Journal of Finance, 68(5), 1805-1841. https://doi.org/10.1111/jofi.12053

Mullineaux, D. J., \& Roten, I. C. (2002). Liquidity, labels and medium-term notes. Financial Markets, Institution and Instruments, 11(5), 401-423. https://doi.org/10.1111/1468-0416.11501

Nashikkar, A., Mahanti, S., Subrahmanyam, M., Chacko, G., \& Mallik, G. (2008). Latent Liquidity: A New Measure of Liquidity, with an Application to Corporate Bonds. Journal of Financial Economics, 88(2), 
272-298. https://doi.org/10.1016/j.jfineco.2007.02.006

O'Hara, M., \& Oldfield, G. (1986). The microeconomics of market making. Journal of Financial and Quantitative Analysis, 21(4), 361-376. https://doi.org/10.2307/2330686

Oliveira, L., Curto, J. D., \& Nunes, J. P. (2012). The determinants of sovereign credit spread changes in the Euro-zone. Journal of International Financial Markets, Institutions and Money, 22(2), 278-304. https://doi.org/10.1016/j.intfin.2011.09.007

Pastor, L., \& Stambaugh, R. F. (2003). Liquidity risk and expected stock returns. Journal of political Economy, 111(3), 642-685. https://doi.org/10.1086/374184

Sadka, R. (2005). Momentum and post-earnings-announcement drift anomalies: The role of liquidity risk. Journal of Financial Economics, 80(2), 309-349. https://doi.org/10.1016/j.jfineco.2005.04.005

Schultz, P. (2001). Corporate bond trading costs: a peak behind the curtain. The Journal of Finance, 56(2), 677-698. https://doi.org/10.1111/0022-1082.00341

Schwarz, K. (2019). Mind the Gap: Disentangling Credit and Liquidity in Risk Spreads. Review of Finance, 23(3), 557-597. https://doi.org/10.1093/rof/rfy034

Sommer, P., \& Pasquali, S. (2016). Liquidity—How to Capture a Multidimensional Beast. The Journal of Trading Spring, 11(2), 21-39. https://doi.org/10.3905/jot.2016.11.2.021

Stoll, H. (1978). The pricing of security dealer services: an empirical study of NASDAQ stocks. The Journal of Finance, 33(4), 1153-1172. https://doi.org/10.1111/j.1540-6261.1978.tb02054.x

Trebbi, F., \& Xiao, K. (2019). Regulation and Market Liquidity. Management Science, 65(5), 1949-2443. https://doi.org/10.1287/mnsc.2017.2876

Üslü, S. (2019). Pricing and Liquidity in Decentralized Asset Markets. Econometrica, 87(6), 2079-2140. https://doi.org/10.3982/ECTA14713

Warga, A. (1992). Bond return, liquidity and missing data. Journal of Financial and Quantitative Analysis, 27(4), 605-617. https://doi.org/10.2307/2331143

\section{Notes}

Note 1. Our sample does not include junk bonds.

Note 2. The EMU Broad Market Index is a composite broad market index (i.e. it gives a description of the total bond market consisting of both sovereign bonds and non-sovereign bonds). About $80 \%$ of the index consists of high-grade AAA and AA bonds. More than $60 \%$ of bonds belong to "Direct government".

\section{Copyrights}

Copyright for this article is retained by the author(s), with first publication rights granted to the journal.

This is an open-access article distributed under the terms and conditions of the Creative Commons Attribution license (http://creativecommons.org/licenses/by/4.0/). 